\title{
Effects of sowing time on pink snow mould, leaf rust and winter damage in winter rye varieties in Finland
}

\author{
Marjo Serenius, Erja Huusela-Veistola, Hanna Avikainen, Katri Pahkala \\ MTT Agrifood Research Finland, Plant Production Research, FI-31600 Jokioinen, Finland, \\ e-mail: erja.huusela-veistola@mtt.fi
}

Antti Laine

MTT Agrifood Research Finland, Southwest Finland Research Station, FI-23120 Mietoinen, Finland

\begin{abstract}
Disease infection in relation to sowing time of winter rye (Secale cereale) was studied in southern Finland in order to compare overwintering capacity of modern rye varieties and to give recommendations for rye cultivation. This was done by using three sowing times and four rye varieties in field trials conducted at three locations in 1999-2001. The early sown rye (beginning of August) was severely affected by diseases caused by Puccinia recondita and Microdochium nivale, whereas postponing sowing for two weeks after the recommended sowing time resulted in considerably less infection. The infection levels of diseases differed among rye varieties. Finnish rye varieties Anna and Bor 7068 were more resistant to snow mould and more winter hardy than the Polish variety Amilo, or the German hybrid varieties Picasso and Esprit. However, Amilo was the most resistant to leaf rust. In the first year snow mould appeared to be the primary cause of winter damage, but in the second year the winter damage was positively correlated with leaf rust. No significant correlation between frit fly infestation and winter damage or disease incidence of snow mould or leaf rust was established. The late sowing of rye (in the beginning of September) is recommended in Finland, particularly with hybrid varieties, to minimize the need for chemical plant protection in autumn.
\end{abstract}

Key words: snow mould, Microdochium nivale, Puccinia recondita, overwintering, winter rye, Secale cereale, frit fly, winter hardening

\section{Introduction}

Cultivated rye in Finland has changed from native landraces, which were common before the 1930s, to population varieties after the 1960s (Paatela 1953, Pessi 1965). Currently varieties from Central Europe represent over $25 \%$ of the winter rye cultivation area (Yearbook of farm statistics 2004). Hybrid rye varieties are becoming more popular 
Vol. 14 (2005): 362-376.

because of the higher yield gain. Overwintering of modern varieties and their reactions to diseases in rye fields can depend on sowing time. Sowing date trials with winter rye done from 1933-1957 indicated that earlier sowings in mid-August were often severely damaged by leaf rust (Puccinia recondita Roberge ex Desmaz.) (Valle 1958). Furthermore, pink snow mould (Microdochium nivale (Fr.) Samuels \& I.C. Hallet, teleomorph: Monographella nivalis (Schaffinit) E. Müller) destroyed overwintered rye sprouts. Thus, the recommended sowing dates in southern Finland were as late as the first week of September (Valle 1958). Later, when insecticides and fungicides were more commonly used, earlier sowings during the two last weeks of August were recommended, based on findings that 265 degree-days were needed for sufficiently strong tillering before winter (Mukula and Rantanen 1989).

Leaf rust is frequent on rye in Europe (Wilson and Henderson 1966, Miedaner et al. 2002), but not so important in Finland (Kangas et al. 2004). Normally rye is sown during the last third of $\mathrm{Au}$ gust in Finland and by sprouting time the temperature has cooled down sufficiently to inhibit the spread of leaf rust. If rye is sown earlier the weather may favour the spread of leaf rust (Linnomäki 1958, Valle 1958, Köylijärvi 1974). Urediospores infect rye in late summer and rust either overwinters with urediospores (Wilson and Henderson 1966) or produces teliospores. However, teliospores are not produced in some environments (Wiese 1987). Leaf rust infection in autumn may be fatal because the infection weakens the overwintering capacity of rye (Pohjakallio 1963).

Pink snow mould is the major cause of overwintering problems of rye in Finland (Jamalainen 1974, Wiese 1987, Hömmö 1994). Pink snow mould can infect all plant parts during wet and cool periods in autumn (Wiese 1987). If snow falls on unfrozen ground the disease can cause severe damage during the winter (Bruehl et al. 1966). Under persistent snow cover the disease develops and destroys the crop. Seed treatment and fungicide application to the canopy just before snow fall are efficient methods to protect rye against snow mould (Wiese 1987, Kangas et al. 2004). In more temperate zones $M$. nivale mainly causes seedling blight, foot rot (Bruehl et al. 1966), and ear blight (Wiese 1987).

In 1999, the research programme "Intensifying rye breeding and cultivation in the Nordic regions" was launched in order to guarantee the continuation of Finnish rye production. The objective of this project was to study whether manipulation of sowing time and introduction of new cultivars could minimize the need for direct crop protection measures in winter rye production. In this paper we describe the part of the project that concentrated on effects of sowing time on overwintering of modern rye varieties. The objective of this part of the project was to compare the effect of sowing time to disease incidence, namely pink snow mould and leaf rust, and winter damage in order to give recommendations for rye cultivation in Finland.

\section{Material and methods}

\section{Field experiment}

The field trials were conducted in south-western Finland where rye production is more prevalent. The field trials were located at experimental sites of MTT Agrifood Research Finland in Jokioinen $\left(60^{\circ} 49^{\prime} \mathrm{N}, \quad 23^{\circ} 28^{\prime} \mathrm{E}\right), \quad$ Mietoinen $\left(60^{\circ} 33^{\prime} \mathrm{N}\right.$, $\left.21^{\circ} 51^{\prime} \mathrm{E}\right)$ and Pälkäne $\left(61^{\circ} 20^{\prime} \mathrm{N}, 24^{\circ} 13^{\prime} \mathrm{E}\right)$. The experiments were sown in autumn 1999 and 2000 and were set up as split-plot designs with four replicates. The main plot factor was sowing time: early (week 32; 9-11 Aug), normally recommended (week 34; 23-25 Aug) and late (week 36; 6-7 Sept) (Table 1). The subplot was rye variety: Anna, a Finnish population variety, Amilo, a Polish short population variety, Bor 7068, a short, Finnish population breeding line and two German hybrid varieties, Esprit in 1999 and Picasso in 2000.

The gross plot size was $1.5 \mathrm{~m} \times 10 \mathrm{~m}$ with a net plot width of $1.25 \mathrm{~m}$. Seeds were sown at a rate of $500 \mathrm{~m}^{-2}$ and a row spacing of $12.5 \mathrm{~cm}$ in ten rows (in Pälkäne twelve rows) per plot. Seeds were coated with fungicide (fenpiclonil, Beret 050 FS) 
Serenius, $M$. et al. Disease infection in relation to sowing time of winter rye

Table 1. Sowing, sprouting and sampling times of the field experiments.

\begin{tabular}{|c|c|c|c|c|c|c|}
\hline & \multicolumn{3}{|c|}{1999} & \multicolumn{3}{|c|}{2000} \\
\hline & Jokioinen & Pälkäne & Mietoinen & Jokioinen & Pälkäne & Mietoinen \\
\hline $\begin{array}{l}\text { Sowing time } \\
\text { early }\end{array}$ & \multicolumn{5}{|c|}{ Sowing time } & 10 Aug \\
\hline normal & $24 \mathrm{Aug}$ & $23 \mathrm{Aug}$ & 23 Aug & $25 \mathrm{Aug}$ & $24 \mathrm{Aug}$ & 24 Aug \\
\hline late & 07 Sep & 06 Sep & 06 Sep & 07 Sep & 07 Sep & 07 Sep \\
\hline \multicolumn{7}{|l|}{ Sprouting time } \\
\hline early & $18 \mathrm{Aug}$ & $16 \mathrm{Aug}$ & $24 \mathrm{Aug}$ & $17 \mathrm{Aug}$ & 16 Aug & 16 Aug \\
\hline normal & 03 Sep & 30 Aug & 02 Sep & 05 Sep & 31 Aug & 06 Sep \\
\hline late & 21 Sep & 14 Sep & 02 Oct & 23 Sep & 20 Sep & 22 Sep \\
\hline \multicolumn{7}{|l|}{ Sampling time } \\
\hline autumn & $12 \mathrm{Oct}$ & $15 \mathrm{Oct}$ & 14 Oct & 09 Oct & 10 Oct & 09 Oct \\
\hline spring & 15 May & 16 May & 17 May & 11 May & 09 May & 14 May \\
\hline Counting of tillers & 27 Oct & 25 Oct & $21 \mathrm{Oct}$ & 16 Oct & $23 \mathrm{Oct}$ & $12 \mathrm{Dec}$ \\
\hline Autumn density & 05 Nov & $21 \mathrm{Oct}$ & 15 Nov & 27 Oct & 19 Oct & $23 \mathrm{Oct}$ \\
\hline Spring density & 02 May & 15 May & $25 \mathrm{Apr}$ & 02 May & 15 May & $30 \mathrm{Apr}$ \\
\hline Snow mould assessment & $20 \mathrm{Apr}$ & $25 \mathrm{Apr}$ & $27 \mathrm{Apr}$ & $27 \mathrm{Apr}$ & $26 \mathrm{Apr}$ & 03 May \\
\hline
\end{tabular}

and seedlings were sprayed with fungicide (prochloraz $450 \mathrm{~g}$ a.i. ha ${ }^{-1}$, Sportak) in autumn after the sprouting. In 1999, insecticide against frit fly (Oscinella frit L.) was applied to the crop only in Mietoinen, but in 2000 all rye plants were sprayed with deltamethrin at the 2-leaf stage.

\section{Weather conditions}

The autumns of 1999 and 2000 were exceptionally warm. In autumn 1999, thermal growing season ended 16-18 October and the daily mean temperature fell below zero Celsius degrees on 14 November (Fig. 1). Permanent snow cover period was shortest in Mietoinen, namely from 14 December to 6 April. In Jokioinen and Pälkäne, there was a permanent snow cover from 2 and 4 December until 8 and 13 April, respectively. In spring 2000 night frosts ceased on 3 April, and the growing season started on 16-18 April.

In autumn 2000 September was colder but October was warmer than the year before (Fig. 1). The thermal growing season ended on 25 October. Permanent snow cover in Mietoinen (from 24 December to 18 March) was more than two weeks shorter than in Jokioinen (from 19 December to 1 April) and more than three weeks shorter than in Pälkäne (from 22 December to 7 April). The latest cold period in spring 2001 was 15 April and the growing season started on 22 April.

The effective temperature sum from the latest sowing time to the end of the growing season ranged from $171^{\circ} \mathrm{C}$ to $242^{\circ} \mathrm{C}$.

\section{Sampling}

The occurrence of leaf rust was assessed in midOctober when the thermal growing season had ceased, and again in early May at the beginning of the growing season (Table 1). The disease was assessed on 20 randomly collected plants per plot. The number of plants infected with leaf rust was recorded, but the disease severity per plant was not assessed. Percentages of infected plants were used in the statistical analyses. Also the length, dry biomass, and number of tillers of those seedlings were measured.

The number of tillers was assessed in one meter of two rows per plot in October, except at Mietoinen in December 2000 (Table 1). The occur- 
Vol. 14 (2005): 362-376.

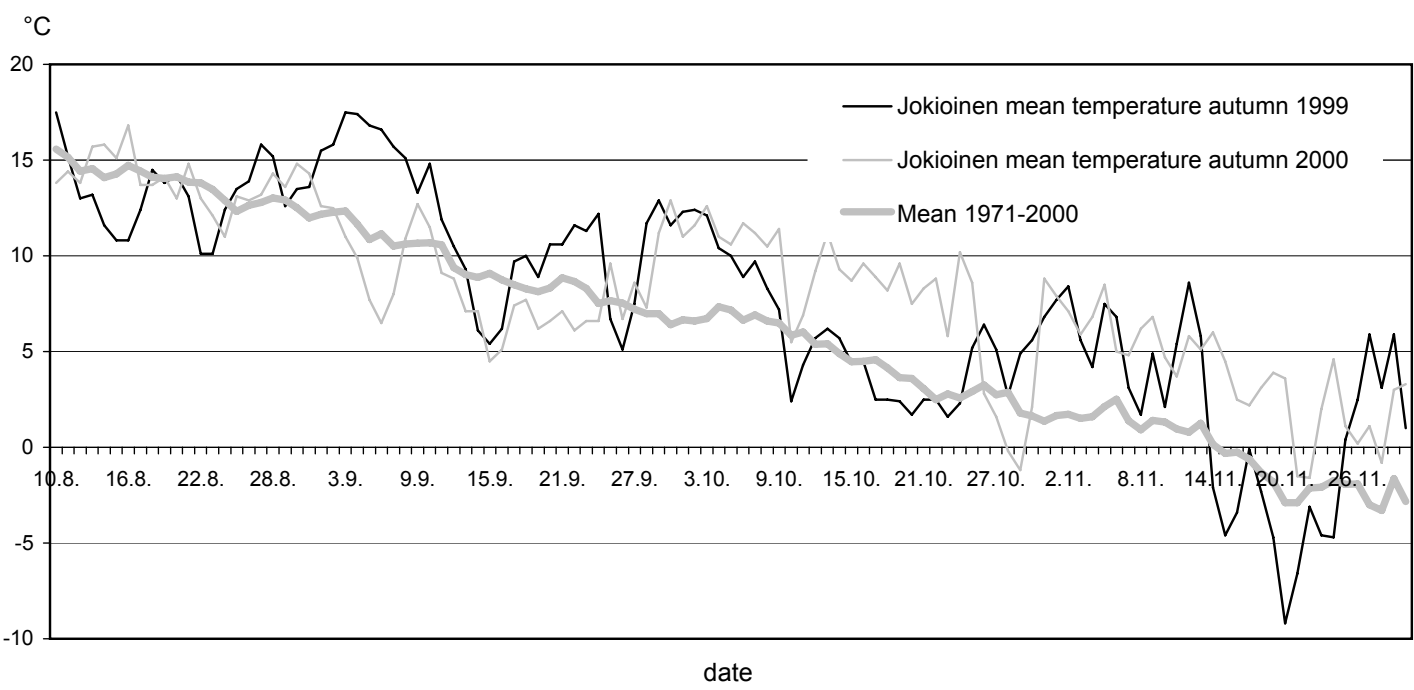

Fig. 1. Daily mean temperature $\left({ }^{\circ} \mathrm{C}\right)$ in Jokioinen in the autumn 1999 and 2000 compared with the mean values from 1971-2000 (Finnish Meteorological Institute).

rence of snow mould was assessed as diseased area $(0-100 \%)$ per plot after snowmelt in late-April (Table 1). The crop density (\%) was assessed visually in autumn and in spring (Table 1). Winter damage was calculated from crop density assessments and expressed as the percentage of dead plants during winter.

\section{Statistical methods}

Statistical analyses were performed using PROC MIXED in SAS/STAT Software (Littell et al. 1996). All experimental designs, randomisations and statistical analyses, except those for repeated measurements, were performed according to Gomez and Gomez (1984). Statistical analyses with repeated measurements were performed according to Gumbertz and Brownie (1993). Assumptions of models were checked using graphical methods; box-plots for normality of errors and plots of residuals for constancy of error variances (Neter et al. 1996) using PROC UNIVARIATE of SAS.
Percentage data on leaf rust incidence were arcsine (square root) transformed prior to analysis as necessary to satisfy conditions of normality and homogeneity of variances. The differences in disease levels in crops among sowing times and varieties in autumn and spring samples were assessed using analysis of variance for repeated measurements with sampling time as a repeated factor in a split-plot design. Winter damage $\%$ and snow mould incidence $(\%)$ data were analysed without a repeated factor. In analysis of leaf rust a standard model for split-split plot design was used. The model was presented in more detailed by Gomez and Gomez (1984, page 142). Leaf rust and snow mould data from one replicate in Pälkäne in spring 2000 were omitted because of herbicide drift from neighbourhood.

In analysis of pink snow mould and winter damage statistical model was:

$\mathrm{Y}_{\mathrm{ijk}}=\mu+$ location $_{\mathrm{i}}+$ block $_{\mathrm{k}}\left(\right.$ location $\left._{\mathrm{i}}\right)+$ sowing time $_{\mathrm{j}}+$ sowing time $_{\mathrm{j}}$ location $_{\mathrm{i}}+$ sowing time $_{\mathrm{j}} \mathrm{X}$ block $_{\mathrm{k}}\left(\right.$ location $\left._{\mathrm{i}}\right)+$ variety $_{1}+$ variety $_{1} \mathrm{x}$ location $_{\mathrm{i}}$ + variety $_{1} x_{\text {sowing }}$ time $_{j}+$ variety $_{1} x$, sowing time $_{\mathrm{j}}$ xlocation $_{\mathrm{i}}+\varepsilon_{\mathrm{ijk}}$ 
Serenius, M. et al. Disease infection in relation to sowing time of winter rye

where location $_{\mathrm{i}}$, sowing time $\mathrm{j}_{\mathrm{j}}$ and variety ${ }_{1}$ represent fixed effects of location, sowing time and variety, respectively. The model has also all interactions of these three effects. $\mu$ is a constant and $\varepsilon_{\mathrm{ijk}}$ is normally distributed residual error. Furthermore, the model has two normally distributed random effects: block $_{\mathrm{k}}\left(\right.$ location $\left._{\mathrm{i}}\right)$ and sowing time $_{\mathrm{j}} \mathrm{x}$ block $_{\mathrm{k}}\left(\right.$ location $\left._{\mathrm{i}}\right)$ which explain variation between blocks within one location and how differences between sowing times vary from block to block within location. Littel et al. (1996) reported an analogous statistical model without the sub-plot factor (i.e. variety). Snow mould and winter damage data from Mietoinen in 2001 were omitted from the analyses because of mistakes made in fungicide application.

Data from all three locations (experiment sites) were analysed together when possible, but data for different years were analysed separately. If the main effects were statistically significant in ANOVA, Tukey's HSD test was used to determine significances of mean differences among factors. If the interaction effects were significant, comparisons were done within each level of the main-plot or sub-plot factor. All presented estimates were transformed to original scale. The standard error of the estimate mean, however, could not be transformed to the original scale.

Relationships between snow mould incidence, winter damage, and vigorousness of rye plant cover in the autumn (crop density, number of tillers per $\mathrm{m}^{2}$, number of leaves or tillers per plant, length and dry biomass of tillers) and levels of plant antagonists (leaf rust and frit fly) were analysed using Pearson correlation analysis of the residuals from ANOVA.

\section{Results}

\section{Leaf rust}

A significant four factor interaction (among sowing time, rye variety, location and sampling time) was observed in both years $(\mathrm{F}=1.87, \mathrm{P}=0.053$ and $\mathrm{F}=2.00 \mathrm{P}=0.034$ ), and therefore analyses were done separately for each location (Tables 2 and 3). In addition, a significant interaction was observed between sowing time and sampling time in both years (Tables 2 and 3).

Parallel results were assessed between locations in both autumns. Most of the (> 50\%) earlysown rye tillers were infected with leaf rust (Table 4). The percentage of infected tillers was markedly reduced (by 25-90\%) following delayed sowing, except in Pälkäne where there was no difference between early sowing and normal sowing time in 1999. Elsewhere the percentage of leaf rust infected tillers was less than $70 \%$, when plants were sown at normal time, and when the sowing was postponed two weeks the infection occurred in less than $10 \%$ of the plants. In most of the cases the

Table 2. ANOVA for percentage of plants infected by leaf rust (Puccinia recondita) by location in 1999-2000. Sampling in October and May.

\begin{tabular}{llccccc}
\hline & \multicolumn{3}{c}{ Jokioinen } & Pälkäne & \multicolumn{2}{c}{ Mietoinen } \\
& d.f. & $\mathrm{F}$ & d.f. & $\mathrm{F}$ & d.f. & $\mathrm{F}$ \\
\hline sowing time & 2,6 & $18.16 * *$ & 2,4 & $27.29 * *$ & 2,6 & $32.36 * * *$ \\
variety & 3,27 & 1.26 & 3,18 & 0.44 & 3,27 & 1.22 \\
sowing time x variety & 6,27 & 1.54 & 6,18 & 0.49 & 6,27 & 0.97 \\
sampling time & 1,3 & 5.10 & 1,2 & $40.99 *$ & 1,3 & $21.28 *$ \\
sowing time x sampling time & 2,6 & $45.45 * * *$ & 2,4 & $72.86 * * *$ & 2,6 & $16.20 * *$ \\
variety x sampling time & 3,27 & $3.76 *$ & 3,18 & 0.55 & 3,27 & $3.07 *$ \\
sowing time x variety x sampling time & 6,27 & 1.82 & 6,18 & 1.99 & 6,27 & $2.52 *$ \\
\hline
\end{tabular}

$*, \mathrm{P}<0.05 ; * *, \mathrm{P}<0.01 ; * * *, \mathrm{P}<0.001$ 
Vol. 14 (2005): 362-376.

Table 3. ANOVA for percentage of plants infected by leaf rust (Puccinia recondita) by location in 2000-2001. Sampling in October and May.

\begin{tabular}{llccccc}
\hline & & Jokioinen & & \multicolumn{2}{c}{ Pälkäne } & \multicolumn{2}{c}{ Mietoinen } \\
& d.f. & $\mathrm{F}$ & d.f. & $\mathrm{F}$ & d.f. & $\mathrm{F}$ \\
\hline sowing time & 2,6 & $53.54 * * *$ & 2,6 & $83.02 * * *$ & 2,6 & $79.38 * * *$ \\
variety & 3,27 & $3.45 *$ & 3,27 & $3.64 *$ & 3,27 & 0.81 \\
sowing time x variety & 6,27 & $2.40 *$ & 6,27 & 1.37 & 6,27 & 0.94 \\
sampling time & 1,3 & $24.69 *$ & 1,3 & 0.19 & 1,3 & $434.85 * * *$ \\
sowing time x sampling time & 2,6 & $117.41 * * *$ & 2,6 & $11.95 * *$ & 2,6 & $76.96 * * *$ \\
variety x sampling time & 3,27 & 0.25 & 3,27 & 0.86 & 3,27 & 1.53 \\
sowing time x variety x sampling time & 6,27 & $4.08 * *$ & 6,27 & 0.60 & 6,27 & 0.34 \\
\hline
\end{tabular}

$*, \mathrm{P}<0.05 ; * *, \mathrm{P}<0.01 ; * * *, \mathrm{P}<0.001$

percentage of infected tillers in spring was in contrast to that in autumn. The leaf rust incidence diminished to less than 50\% and even to zero during the winter among the early sown plants, except in Pälkäne in 2001, where the spring leaf rust incidence in early sown plants except 'Amilo' was nearly $60 \%$ (Table 4 ).

Leaf rust incidence did not differ among varieties in Pälkäne in 1999 and in Mietoinen in 2000 (Tables 2 and 3) but a significant variety effect was observed at other times and locations. The lowest leaf rust incidence was observed in 'Amilo' in most cases.

\section{Pink snow mould}

In spring 2000 infection level of snow mould was very low (less than 5\%) in Mietoinen and therefore those data were excluded from statistical analyses and are not shown. In the second year, fungicide treatment was not done in Mietoinen, and therefore snow mould data from year 2001 were also excluded.

Delayed sowing time decreased snow mould infection in both years (Table 5). However, a significant interaction was recorded among variety, location, and sowing time in both years (Table 6). As a result, the snow mould infection rate differed in Pälkäne in spring 2000, where plants sown at normal time had higher infection rate than the early sown plants, which was in contrast with other results.

'Anna' and Bor 7068 were more resistant to snow mould than 'Amilo' or hybrid varieties at both locations and years (Table 5). The differences among varieties were clearest on crops sown at the normal time.

\section{Winter damage}

Winter damage was calculated using visual assessments from crop density (\%) in late autumn and in early spring. During the first winter, the interaction among sowing time, variety, and location was significant, which was contrary to results furnished by Mietoinen (Table 7, Fig. 2). In Mietoinen, late sown plots suffered the most winter damage but at other locations winter damage was highest in early sown plots. In contrast, sowing time did not seem to have any affect on winter damage on 'Amilo' in Pälkäne in the first year (Fig. 2). This was somewhat in accordance with snow mould results (Table 5). In the second year, the effect of sowing time on winter damage was significantly dependent on location (Table 7). In Jokioinen winter damage was severest in early sown plots and clearly less at other sowing times as in first year (Fig. 3). However, in Pälkäne the amount of winter damage differed among rye varieties and the differences between sowing times were not so clear. Overall, winter damage level was clearly less in the second year than in the previous year (Figs 2 and 3). Amilo and the hybrid varieties suffered most from winter damage, although the difference among varieties depended on location and sowing time (Table 7, Fig. 3). 
Serenius, $M$. et al. Disease infection in relation to sowing time of winter rye

Table 4. Percentage of plants infected by leaf rust (Puccinia recondita) by location, sowing time and variety in 19992000 and 2000-2001. Sowing times: early = week 32, normal $=$ week 34 , late $=$ week 36.

\begin{tabular}{|c|c|c|c|c|c|c|c|}
\hline Sampling time & Location & Sowing time & Anna & Amilo & $\begin{array}{c}\text { Variety } \\
\text { Bor } 7068\end{array}$ & Esprit & Picasso \\
\hline \multirow[t]{9}{*}{ Autumn 1999} & Jokioinen & early & 87.1 & 62.6 & 78.5 & 87.8 & \\
\hline & & normal & 29.7 & 15.7 & 12.2 & 13.5 & \\
\hline & & late & 0.0 & 0.0 & 0.0 & 0.0 & \\
\hline & Pälkäne & early & 100.0 & 100.0 & 100.0 & 100.0 & \\
\hline & & normal & 100.0 & 99.4 & 99.4 & 100.0 & \\
\hline & & late & 2.2 & 5.6 & 7.7 & 3.7 & \\
\hline & Mietoinen & early & 94.3 & 76.2 & 67.4 & 85.6 & \\
\hline & & normal & 42.3 & 20.9 & 32.4 & 36.7 & \\
\hline & & late & 0.0 & 0.3 & 0.6 & 0.0 & \\
\hline \multirow[t]{9}{*}{ Spring 2000} & Jokioinen & early & 9.7 & 7.9 & 19.9 & 7.5 & \\
\hline & & normal & 4.6 & 19.4 & 10.3 & 16.5 & \\
\hline & & late & 10.6 & 12.3 & 27.5 & 36.8 & \\
\hline & Pälkäne & early & 8.0 & 3.3 & 1.7 & 5.6 & \\
\hline & & normal & 9.6 & 14.4 & 18.3 & 12.2 & \\
\hline & & late & 27.9 & 27.0 & 25.8 & 45.5 & \\
\hline & Mietoinen & early & 12.4 & 22.3 & 41.0 & 29.4 & \\
\hline & & normal & 12.4 & 5.5 & 12.9 & 7.2 & \\
\hline & & late & 3.7 & 3.7 & 4.6 & 1.9 & \\
\hline \multirow[t]{9}{*}{ Autumn 2000} & Jokioinen & early & 98.7 & 56.1 & 95.3 & & 84.9 \\
\hline & & normal & 1.9 & 3.7 & 1.3 & & 5.1 \\
\hline & & late & 0.0 & 0.3 & 0.0 & & 0.0 \\
\hline & Pälkäne & early & 89.8 & 79.2 & 82.9 & & 84.5 \\
\hline & & normal & 13.8 & 8.8 & 14.8 & & 8.9 \\
\hline & & late & 7.7 & 7.2 & 4.4 & & 4.6 \\
\hline & Mietoinen & early & 99.7 & 99.7 & 99.4 & & 99.7 \\
\hline & & normal & 73.9 & 56.4 & 72.7 & & 66.8 \\
\hline & & late & 9.4 & 7.5 & 16.6 & & 9.7 \\
\hline \multirow[t]{9}{*}{ Spring 2001} & Jokioinen & early & 6.3 & 1.3 & 2.8 & & 2.4 \\
\hline & & normal & 6.6 & 0.3 & 9.5 & & 1.9 \\
\hline & & late & 21.3 & 18.0 & 13.9 & & 16.4 \\
\hline & Pälkäne & early & 59.1 & 27.0 & 58.8 & & 57.2 \\
\hline & & normal & 21.0 & 13.0 & 19.6 & & 17.8 \\
\hline & & late & 22.8 & 11.3 & 8.8 & & 8.7 \\
\hline & Mietoinen & early & 0.0 & 1.3 & 0.3 & & 2.8 \\
\hline & & normal & 0.0 & 0.0 & 0.6 & & 0.0 \\
\hline & & late & 0.0 & 0.3 & 0.3 & & 0.3 \\
\hline
\end{tabular}

\section{Seedlings}

Plants were taller before hardening in autumn 1999 than in 2000. Early sown seedlings were largest and most vigorous and had 6-10 and 4-8 tillers per plant in 1999 and 2000, respectively. Seedlings from seed sown at the normal time had 4-5 and 2-6 tillers per plant and late sown seedlings had only 1-4 and 1-2 tillers per plant in 1999 and 2000, respectively. In Pälkäne, emergence of rye seedlings was quicker and more tillers were observed for seedlings that developed from rye sown 
Vol. 14 (2005): 362-376.

Table 5. Snow mould (Microdochium nivale) by location, variety and sowing time in spring 2000 and 2001.

Sowing times: early $=$ week 32 , normal $=$ week 34 , late $=$ week 36.

\begin{tabular}{|c|c|c|c|c|c|c|c|}
\hline Sampling time & Location & Sowing time & Anna & Amilo & $\begin{array}{c}\text { Variety } \\
\text { Bor } 7068\end{array}$ & Esprit & Picasso \\
\hline \multirow{6}{*}{ Spring 2000} & Jokioinen & early & 43.8 & 70.0 & 40.8 & 75.0 & \\
\hline & & normal & 21.0 & 47.5 & 11.3 & 31.0 & \\
\hline & & late & 1.0 & 16.3 & 0.3 & 0.9 & \\
\hline & Pälkäne & early & 46.7 & 53.3 & 36.7 & 68.3 & \\
\hline & & normal & 56.7 & 76.7 & 48.3 & 76.7 & \\
\hline & & late & 30.0 & 63.3 & 2.2 & 48.3 & \\
\hline \multirow[t]{6}{*}{ Spring 2001} & Jokioinen & early & 45.0 & 52.5 & 44.5 & & 58.8 \\
\hline & & normal & 15.0 & 37.5 & 17.5 & & 51.3 \\
\hline & & late & 1.5 & 8.9 & 1.6 & & 25.0 \\
\hline & Pälkäne & early & 37.8 & 52.5 & 40.8 & & 57.5 \\
\hline & & normal & 25.3 & 46.3 & 22.0 & & 45.0 \\
\hline & & late & 0.1 & 4.1 & 0.1 & & 3.9 \\
\hline
\end{tabular}

Table 6. ANOVA for percentage incidence of snow mould (Microdochium nivale). Data from Mietoinen not included in analyses.

\begin{tabular}{llrrc}
\hline & & $1999-2000$ & \multicolumn{2}{c}{$2000-2001$} \\
& d.f. & $\mathrm{F}$ & d.f. & $\mathrm{F}$ \\
\hline location & 1,5 & $100.18 * * *$ & 1,6 & 0.43 \\
sowing time & 2,10 & $98.63 * * *$ & 2,12 & $131.17 * * *$ \\
sowing time x location & 2,10 & $42.33 * * *$ & 2,12 & 2.36 \\
variety & 3,44 & $78.17 * * *$ & 3,54 & $69.16 * * *$ \\
variety $*$ sowing time & 3,44 & $4.73 * *$ & 3,54 & $4.81 * *$ \\
variety x location & 6,44 & $3.70 * *$ & 6,54 & $5.45 * * *$ \\
variety x location x sowing time & 6,44 & $6.48 * * *$ & 6,54 & $2.39 *$ \\
\hline
\end{tabular}

$*, \mathrm{P}<0.05 ; * *, \mathrm{P}<0.01 ; * * *, \mathrm{P}<0.001$

Table 7. ANOVA for winter damage. In 2000-2001 data from Mietoinen not included in analyses.

\begin{tabular}{llccc}
\hline & & $1999-2000$ & & $2000-2001$ \\
& d.f. & $\mathrm{F}$ & d.f. & $\mathrm{F}$ \\
\hline location & 2.8 & $5.76 *$ & 1.6 & 7.38 \\
sowing time & 2,16 & $17.81 * * *$ & 2,12 & $53.60 * * *$ \\
sowing time x location & 2,16 & $41.69 * * *$ & 2,12 & $22.01 * * *$ \\
variety & 3,72 & $96.57 * * *$ & 3,54 & $39.44 * * *$ \\
variety * sowing time & 3,72 & $28.63 * * *$ & 3,54 & $6.11 * *$ \\
variety x location & 6,72 & $12.69 * * *$ & 6,54 & $9.45 * * *$ \\
variety x location x sowing time & 6,72 & $14.62 * * *$ & 6,54 & 1.63 \\
\hline
\end{tabular}

*. $\mathrm{P}<0.05 ; * * . \mathrm{P}<0.01 ; * * * . \mathrm{P}<0.001$

at the normal time than for those from early sown seed at other locations. Differences between varieties were significant $(\mathrm{P}<0.05)$ only in early sowings, where 'Esprit' had significantly more tillers than others in 1999, and 'Anna' the most and 'Picasso' the least tillers in 2000. This was calculated over all locations. 
Serenius, $M$. et al. Disease infection in relation to sowing time of winter rye

Fig. 2. Winter damage (\%) by location, variety and sowing time in winter 1999/2000. Sowing times: early $=$ week 32 , normal $=$ week 34 , late $=$ week 36 .

Fig. 3. Winter damage (\%) by location, variety and sowing time in winter 2000/2001. Sowing times: early $=$ week 32 , normal $=$ week 34 , late $=$ week 36 .

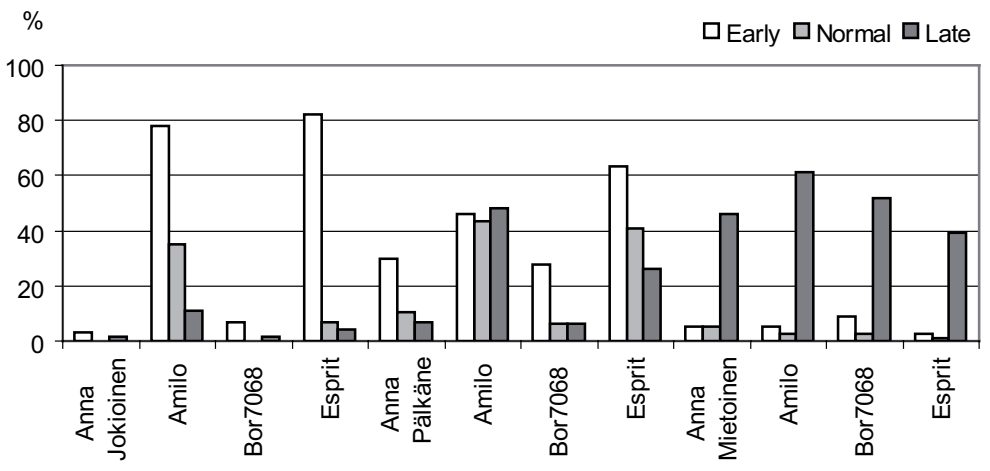

$\%$ Early $\square$ Normal $\square$ Late

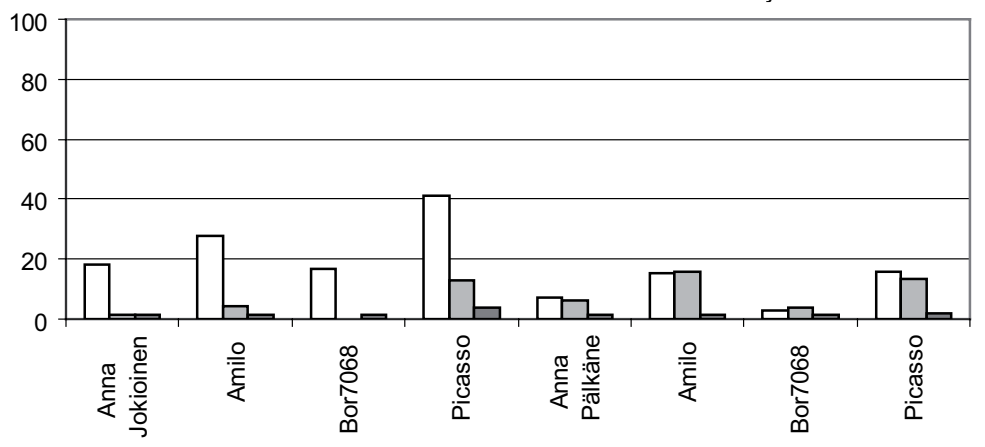

\section{Correlation between factors}

Analysis of residuals from ANOVA indicated low but significant correlations between some factors. Pink snow mould incidence was positively correlated with number of tillers $\mathrm{m}^{-2}(\mathrm{n}=83, \mathrm{r}=0.34, \mathrm{P}$ $=0.002)$, and winter damage $(\mathrm{n}=83, \mathrm{r}=0.19, \mathrm{P}=$ $0.092)$ in the first year, but not in the second year ( $\mathrm{r}$ $=-0.01, P=0.989)$ and $(r=0.12, P=0.244)$, respectively. Furthermore, winter damage and dry biomass of seedlings measured in the previous autumn were negatively correlated $(\mathrm{n}=132, \mathrm{r}=$ $-0.19, \mathrm{P}=0.031$ ) in the first year. However, in the second year the winter damage severity was only half that of the first year. Nonetheless, snow mould incidence was positively correlated with seedling height ( $\mathrm{n}=96, \mathrm{r}=0.18, \mathrm{P}=0.072)$ in the second year. In addition, the winter damage correlated positively with seedling height $(\mathrm{n}=96, \mathrm{r}=0.27, \mathrm{P}$ $=0.007)$, with number of leaves per plant $(n=96$, $r=0.18, P=0.075)$ and incidence of leaf rust $(n=$
$96, r=0.18, P=0.073$ ) measured in the previous autumn. In contrast, in the first year these correlations were negative and mostly non-significant $(\mathrm{r}=$ $-0.15, \mathrm{P}=0.083 ; \mathrm{r}=-0.09, \mathrm{P}=0.325$ and $\mathrm{r}=$ $-0.17, \mathrm{P}=0.047$, respectively).

No significant correlation between snow mould infection and growth stage of seedlings in the previous autumn was established. Neither significant correlation between frit fly infestation and winter damage nor disease incidence of snow mould or leaf rust was established.

\section{Discussion}

The objective of this research was to review the recommendations for rye cultivation in Finland, since hybrid varieties are becoming more popular, and more importantly they are mostly of central 
Vol. 14 (2005): 362-376.

European origin. The sowing time affects plant development in autumn, and winter hardening, both of which are important under northern cultivation conditions. Our study concentrated on overwintering of rye, and therefore the effects on crop yield and quality were not measured. Both study years were milder than average (Fig. 1). As a result, the latest sowing time (week 36) suffered least from autumn leaf rust, pink snow mould or winter damage. However, due to late sowing the sprouting of rye was delayed until as late as the beginning of October (Table 1), which is far too close to the end of the thermal growing season (16 Oct in 1999 and 25 Oct in 2000). Overwintering of rye depends on several factors, which are discussed further.

\section{Sowing time}

In both autumns leaf rust infection was highest in early sown winter rye, which is in accordance with earlier studies conducted on rye in Finland (Anttinen 1958, Honkavaara 1958, Linnomäki 1958, Valle 1958, Köylijärvi 1974), and on winter wheat, and on triticale (Triticale hexaploide Lart.) in Sweden (Olvång 1987, 1996). Early sown crops may become infected with leaf rust derived from previous year's rye cultivation in the surrounding area. At the end of August the weather can be very warm in Finland, which favours the development and spread of leaf rust. In the first year, we observed a positive correlation between leaf rust and plant size (the number of leaves and tillers per plant).

During the winter, leaf rust infection decreased in early sowings but increased in late sowings in Jokioinen and Pälkäne. It is possible that the most infected leaves died during the winter but less infected leaves survived. The leaf rust infection weakens seedlings' overwintering capacity (Pohjakallio 1963). Leaf rust is able to survive in viable leaves as a mycelium and as urediospores (Mains 1923, Pohjakallio 1963, Wilson and Henderson 1966). Current results show that leaf rust is able to overwinter also in Finland, and overwintered urediospores may serve as a inoculum source in spring. To date leaf rust has not been a serious dis- ease on rye during the summer growing season (Kangas et al. 2004).

In previous sowing time experiments in Finland (Honkavaara 1958, Valle 1958), occurrence of leaf rust was connected with occurrence of frit flies in early sown rye during autumn. In our studies, both leaf rust and frit flies were abundant in early sown plots in autumn 1999 (Huusela-Veistola et al., unpublished results). However, leaf rust infection level was high also in the second autumn, when the number of frit flies was low following the insecticide treatment. Therefore, no significant correlation between frit fly infestation level and leaf rust infection was found.

\section{Winter hardening}

According to Pulli (1987), warm, cloudy and moist weather conditions can prevent rye from becoming winterhardy. In this study, the pink snow mould infection was higher in both years than on average in Finnish official variety trials (Kangas et al. 2004, 2005). Both autumns were also warmer than on average (Fig. 1). The daily mean temperature dropped permanently below $5^{\circ} \mathrm{C}$ in mid-October in 1999, and at the end of October in 2000, which is later than in an average year. The best hardening and snow mould resistance is achieved when rye is exposed to a constant temperature of $1^{\circ} \mathrm{C}$ (Miedaner et al. 1993). Several researchers have shown that hardening increases resistance to diseases (e.g. Årsvoll 1977, Miedaner et al. 1993, Gaudet 1994, Hömmö 1994). Therefore, the observed higher pink snow mould infestation may be a result of insufficient hardening. The resistance of seedlings to snow mould is connected with the carbohydrate metabolism (Chen 1994, Hömmö 1994, Gaudet et al. 1999, Yoshida et al. 1998) and pathogenesisrelated antifreeze proteins (Ergon et al. 1998, Hiilovaara-Teijo et al. 1999, Yu et al. 2001) during the hardening period and winter. Carbohydrate reserves are important for overwintering of rye in cold climates, and are the main carbon source for the initial spring growth (Hurry et al. 1995). Hakala and Pahkala (2001) showed that carbohydrate content of rye leaves was higher the later the sow- 
Serenius, M. et al. Disease infection in relation to sowing time of winter rye

ing, especially in 'Amilo'. However, severe winter damage without snow mould was observed in Mietoinen in late sown plants in 1999/2000, when plants had only two weeks of thermal growing season to establish the carbohydrate reserves. This indicates that postponing the sowing time until too close to the end of the growing season leads to insufficient hardening. Both Finnish and central European rye varieties can harden and reach a good overwintering status under northern growing conditions, if the weather turns steadily cold during autumn (Hakala and Pahkala 2003). However, if temperature fluctuates it is possible that early sown foreign varieties deharden and start to metabolise their reserve sugars, while Finnish varieties remain dormant. On the other hand, later sown varieties may benefit from warm periods and increase their sugar content (Hakala and Pahkala 2003).

If soil is not frozen before snow falls on the ground, snow mould, which develops under the snow (Wiese 1987), often destroys the rye stand (Mukula and Rantanen 1989). In accordance with earlier results, we observed less snow mould infection in Mietoinen than in Jokioinen or Pälkäne. The snow cover is thinner in south-west and western Finland, as in Mietoinen, than in central or eastern Finland, and results in less snow mould infection (Jamalainen 1958, 1962, 1974).

\section{Rye variety}

Rye varieties differed in leaf rust infection level (resistance) but the effect of variety depended also on location and sowing time. 'Amilo' was most often the least infected variety in autumn. Also in Finnish official variety trials, 'Amilo' has been significantly $(\mathrm{P}<0.05)$ more resistant to leaf rust compared to 'Picasso' or 'Esprit' during the summer growing season (Kangas et al. 2004). However, leaf rust of rye is among the least important diseases in Finland (disease incidence on average less than $2 \%$ ) compared to the total amount of leaf spots (max 13\%) on rye (Kangas et al. 2004). Furthermore, the autumn infection has not been assessed earlier. This study shows that leaf rust is capable of surviving the winter in Finland. There- fore, 'Amilo' would be a good variety to use in early sowings, when there is a higher risk of leaf rust infection. However, 'Amilo' benefits from late sowing (Hakala and Pahkala 2001), which extends the sowing time for that specific variety.

The previous studies show that variety, size and growth stage of seedlings are important for pink snow mould resistance (Jamalainen 1974, Årsvoll 1977, Miedaner et al. 1993). Early sown, very strong and vigorous seedlings, as well as very late sown seedlings with only 2-3 leaves, were the most susceptible to snow mould in Finland (Linnomäki 1958, Valle 1958, Jamalainen 1962, 1974, Vanhanen 1980). In this study, the most severe pink snow mould infection was observed in early sown plants except in one year in Pälkäne, where the severest damage was in plants sown at the normal time. However, those tillers were comparably more vigorous than elsewhere. In line with the Finnish studies, Miedaner et al. (1993) noticed that very small plants (1-3 leaves) are more susceptible to pink snow mould than those with multiple tillers. Also, Årsvoll (1977) noticed that large graminaceous plants are resistant to pink snow mould.

In current study, Finnish rye varieties 'Anna' and Bor 7068 were more resistant to pink snow mould than 'Amilo' or the hybrid varieties 'Picasso' and 'Esprit'. This is in accordance with the Finnish official rye variety trial results (Kangas et al. 2004). 'Anna' has also shown slight resistance to pink snow mould in other experiments (Vanhanen 1980, Hömmö et al. 1993, Hömmö 1994). In general, the old northern Scandinavian rye varieties have been more resistant in Finland against snow mould than central European ones (Jamalainen 1974, Kangas et al. 2004). Because 'Amilo' and hybrid varieties are more susceptible to snow mould in Finland it may be necessary to use fungicide, which has proven to diminish the winter damage by 14 to $20 \%$ (Serenius et al. 2001, Kangas et al. 2005). Even though our experiments were treated with fungicides, there was a significant difference among varieties in pink snow mould incidence. 'Amilo' and hybrid varieties 'Esprit' and 'Picasso' suffered also most severely from winter damage, which is also in accordance with the official variety trials (Kangas et al. 2005). 
Vol. 14 (2005): 362-376.

Since use of resistant varieties is more environmentally friendly than use of fungicides, it would be appropriate to introduce leaf rust resistance (Miedaner et al. 2002) into Finnish pink snow mould tolerant varieties. However, this needs further research.

\section{Other factors}

Both abiotic and biotic stresses may predispose plants to winter stresses (Wiese 1987). Snow cover is an important factor in the extent of damage caused by snow mould, but water and ice can kill rye plants during the winter, especially, after the snow melts (Mukula and Rantanen 1989). In earlier experiments (Anttinen 1958, Valle 1958), winter damage was correlated with damage caused by leaf rust and frit fly. In our experiments, winter damage was negatively correlated with autumn leaf rust infection in winter 1999/2000, when snow mould appeared to be the primary cause of winter damage. In the second year, the winter damage was positively correlated with leaf rust. Significant correlation between winter damage and infestation level of frit fly was not established.

In Mietoinen, the late sown plots suffered most severely from winter damage, which was significantly different than elsewhere. The plots suffered mostly from heavy rainfall between 23 September and 11 October and therefore the sprouting of tillers was delayed (Table 1). Therefore, delaying the sowing time may represent a risk. Delayed sprouting of tillers also shortens the winter hardening time. According to Hakala and Pahkala (2003), leaf elongation of rye varieties ceases but tillering continues during the hardening period.

\section{Conclusions}

Since the effects of diseases on rye grain yield were not measured in these experiments the interpretation of results concentrates only on overwintering conditions. Sowing time has a significant effect on diseases in winter rye. Early sowing usually resulted in the most severe problems with overwintering. In addition, incidence of diseases and level of winter damage differed among varieties: Finnish varieties 'Anna' and Bor 7068 were more resistant to pink snow mould and winter damage than the Polish variety 'Amilo' or the German hybrid varieties 'Picasso' and 'Esprit'. On the other hand, 'Amilo' was the least infected with leaf rust. According to our results, early sowing of rye is risky. Current normal or later sowing of rye is recommended, especially with new hybrid cultivars. Damage from diseases can be reduced by postponing the sowing time, which can also be practised in organic production. However, the autumns 1999 and 2000 were exceptionally warm. In colder autumns late sown tillers can be too small and will not have had enough time to harden. Late sowing can become difficult or even be prevented because of rainy or cold weather. Fungicide application against snow mould is recommended for susceptible varieties especially in regions where snow cover is thick and persists. However, adapted and resistant cultivars are a prerequisite for successful rye cultivation under northern conditions.

Acknowledgements. The authors acknowledge the co-ordination of the rye research programme by Dr. Simo Hovinen, biometrician Lauri Jauhiainen for statistical consultation, and Dr. Jukka Salonen for help with the manuscript. We also wish to thank the staff of MTT Plant production in Jokioinen and at MTT Research Stations in Mietoinen and Pälkäne for technical assistance in the field experiments. The study was funded by the Ministry of Agriculture and Forestry and MTT Agrifood Research Finland.

\section{References}

Anttinen, O. 1958. Syysrukiin kylvöaikakokeet Pohjois-Pohjanmaan koeasemalla. Summary: Sowing time trials with winter rye at North Pohjanmaa Experimental Station. In: Mukula, J. (ed.). Maatalous ja koetoiminta 1958, 12: $154-158$.

Årsvoll, K.1977. Effects of hardening, plant age, and development in Phleum pratense and Festuca pratensis on resistance to snow mould fungi. Meldinger fra Norges LandbruksHøgskole 56. 14 p. 


\section{AGRICULTURAL AND FOOD SCIENCE}

\section{Serenius, M. et al. Disease infection in relation to sowing time of winter rye}

Bruehl, G.W., Sprague, R., Fischer, W.R., Nagamitsu, M., Nelson, W.L. \& Vogel, O.A. 1966. Snow moulds of winter wheat in Washington. Bulletin - Washington Agricultural Experiment Station 677: 1-21.

Chen, T.H.H. 1994. Plant adaptation to low temperature stress. Canadian Journal of Plant Pathology 16: 231236.

Ergon, Å., Klemsdal, S.S. \& Tronsmo, A.M. 1998. Interaction between cold hardening and Microdochium nivale infection on expression of pathogenesis-related genes in winter wheat. Physiological and Molecular Plant Pathology 53: 301-310.

Gaudet, D.A. 1994. Progress towards understanding interactions between cold hardiness and snow mold resistance and development of resistant cultivars. Canadian Journal of Plant Pathology 16: 241-246.

Gaudet, D.A., Laroche, A. \& Yoshida, M. 1999. Low temperature-wheat-fungal interactions: A carbohydrate connection. Physiologia Plantarum 106: 37-44.

Gomez, K.A. \& Gomez, A.A. 1984. Statistical procedures for agricultural research. 2nd ed. John Wiley \& Sons, New York. 627 p.

Gumbertz, M.L. \& Brownie, C. 1993. Repeated measures in randomized block and split-plot experiments. Canadian Journal of Forest Research 23: 625-639.

Hakala, K. \& Pahkala, K. 2001. Carbohydrate metabolism in winter rye (Secale cereale L.). In: 6th International plant cold hardiness seminar. Helsinki, Finland 1-5 July 2001. Abstracts book and final programme. Helsinki, University of Helsinki. p. 45.

Hakala, K. \& Pahkala, K. 2003. Comparison of central and northern European winter rye cultivars grown at high latitudes. Journal of Agricultural Science 141: 169178.

Hiilovaara-Teijo, M., Hannukkala, A., Griffith, M., Yu, X.-M. \& Pihakoski-Maunsbach, K. 1999. Snow mould induced apoplastic proteins in winter rye leaves lack antifreeze activity. Plant Physiology 121: 655-673.

Hömmö, L.M. 1994. Resistance of winter cereals to various winter stress factors - inter- and intraspecific variation and the role of cold acclimation. Agricultural Science in Finland 3: Supplement No. 1. 32 p. Academic dissertation, University of Turku.

Hömmö, L., Hannukkala, A. \& Pulli, S. 1993. Screening for resistance of winter wheat and rye varieties to Finnish snow mould (Microdochium nivale) isolates. Hodowla Roslin Aklimatyzacja i Nasiennictwo 37 (Special issue No. 2): 133-140.

Honkavaara, T. 1958. Syysviljojen kylvöaikakokeet EteläPohjanmaan koeasemalla. Summary: Saatzeitversuche mit Wintergetreide in der Versuchstation für SüdPohjanmaa. In: Mukula, J. (ed.). Maatalous ja koetoiminta 1958, 12: 177-187.

Hurry, V., Tobiaeson, M., Krömer, S., Gardenström, P. \& Öquist, G. 1995. Mitochondria contribute to increased photosynthetic capacity of leaves of winter rye (Secale cereale L.) following cold-hardening. Plant, Cell and Environment 18: 69-76.

Jamalainen, E.A. 1958. Peltokasvien huonon talvehtimisen syistä ja talvituhosienien aiheuttamien vahinkojen torjuntatoimenpiteistä. Summary: On reasons for poor overwintering of field crops and control measures against damage caused by low-temperature parasitic fungi. In: Mukula, J. (ed.). Maatalous ja koetoiminta 1958, 12: 55-63.

Jamalainen, E.A. 1962. Trials on seed treatment of winter cereals in Finland. Annales Agriculturae Fenniae 1: 175-191.

Jamalainen, E.A. 1974. Resistance in winter cereals and grasses to low-temperature parasitic fungi. Annual Review of Phytopathology 12: 281-30.

Kangas, A., Kedonperä, A., Laine, A., Lindroos, M., Niskanen, M., Salo, Y., Vuorinen, M., Jauhiainen, L. \& Ramstadius, E. 2004. Viljalajikkeiden herkkyys tautitartunnoille virallisissa lajikekokeissa 1997-2004. (Disease susceptibility of cereal varieties in Finnish official variety trials 1997-2004, with English subtitles). MTT:n selvityksiä $77.31 \mathrm{p}$.

Kangas, A., Laine, A., Niskanen, M., Salo, Y., Vuorinen, M., Jauhiainen, L. \& Nikander, H. 2005. Virallisten lajikekokeiden tulokset 1997-2004. (Results of official variety trials 1997-2004, with English subtitles). MTT:n selvityksiä 83. 193 p.

Köylijärvi, J. 1974. Syysviljojen kylvö Lounais-Suomen oloissa. Koetoiminta ja käytäntö 8.

Linnomäki, H. 1958. Syysrukiin kylvöaikakokeet Hämeen koeasemalla. Summary: Sowing time trials with winter rye at Häme Experimental Station. In: Mukula, J. (ed.). Maatalous ja koetoiminta 1958, 12: 147-153.

Littell, R.C., Milliken, G.A., Stroup, W.W. \& Wolfinger, R.D. 1996. SAS system for mixed models. SAS Institute INC, Gary, NC. 633 p.

Mains, E.B. 1923. Resistance in rye to leaf rust, Puccinia dispersa Erikss. Journal of Agricultural Research 25/5: 243-252.

Miedaner, T., Höxter, H. \& Geiger, H.H. 1993. Development of a resistance test for winter rye to snow mould (Microdochium nivale) under controlled environment conditions in regard to field inoculations. Canadian Journal of Botany 71: 136-144.

Miedaner, T., Gey, A.K.M., Sperling, U. \& Geiger, H.H. 2002. Quantitative-genetic analysis of leaf-rust resistance in seedling and adult-plant stages of inbred lines and their testcrosses in winter rye. Plant Breeding 121, 6: 475-479.

Mukula, J. \& Rantanen, O. 1989. Climatic risks to the yield and quality of field crops in Finland: III.Winter rye 1969-1986. Annales Agriculturae Fenniae 28: 3-11.

Neter, J., Kutner, M., Nachtsheim, C. \& Wasserman, W. 1996. Applied linear statistical models. 4th edition. Irwin, Chicago, USA. $1310 \mathrm{p}$.

Olvång, H. 1987. Bekämpning av utvintringssvampar i höstvete och råg. Växtskyddsnotiser 51, 3: 74-80.

Olvång, H. 1996. How does time of sowing and amount of seed affect the risk for fungal diseases in winter cereal - particularly rye wheat. 37 th Swedish Crop Protection Conference. p. 221-231.

Paatela. J. 1953. Tärkeimmät viljalajikkeemme ja niiden viljelyalueet. Summary: The most important varieties of cereal grown in Finland and their growing areas. Acta Agralia Fennica 80, 1.78 p.

Pessi, Y. 1965. Agriculture in Northern Fennoscandia. Part III. Agricultural research work in Finland. Acta Agriculturae Scandinavica. Supplementum 13. p. 117-124. 
Vol. 14 (2005): 362-376.

Pohjakallio, O. 1963. Kasvipatologia II. Tarttuvat kasvitaudit. $375 \mathrm{p}$.

Pulli, S. 1987. Rukiin kylvö ja talvehtiminen. In: Symposium rukiin viljely, Jokioinen 17.11.1986. Suomen Maataloustieteellisen Seuran tiedote no. 8. p. 20-29.

Serenius, M., Avikainen, H., Kedonperä, A., Lindroos, M., Peltomäki, E., Salonen, J. \& Hovinen, S. 2001. The benefit of fungicide application against snow mould depends on rye variety. In: Proceeding of the EUCARPIA rye meeting, 4-7 July 2001, Radzików, Poland. p. 269270.

Valle, O. 1958. Kylvöajan merkityksestä syysrukiin ja syysvehnän viljelyssä Etelä-Suomessa. Summary: The influence of sowing time on the cultivation of winter rye and winter wheat in South Finland. In: Mukula, J. (ed.). Maatalous ja koetoiminta 1958, 12: 159-176.

Vanhanen, R. 1980. Talvituhot kuriin ruiskuttamalla. Koetoiminta ja käytäntö 37: 37.
Wiese, M.V. (ed.). 1987. Compendium of wheat diseases. APS: Press, St. Paul, Minnesota. 112 p.

Wilson, M. \& Henderson, D.M. 1966. British rust fungi. Cambridge University Press. Cambridge. 384 p.

Yearbook of Farm Statistics 2004. Information Centre of the Ministry of Agriculture and Forestry, Helsinki, Finland. Official statistics of Finland. Agriculture, forestry and fishery 2004, 61. $268 \mathrm{p}$.

Yoshida, M., Abe, J., Moriyama, M. \& Kuwabara, T. 1998. Carbohydrate levels among winter wheat cultivars varying in freezing tolerance and snow mould resistance during autumn and winter. Physiologia Plantarum 103: 8-16.

Yu, X.-M., Griffith, M. \& Wiseman, S.B. 2001. Ethylene induces antifreeze activity in winter rye leaves. Plant Physiology 126: 1232-1240.

\title{
SELOSTUS
}

\section{Kylvöajan ja lajikkeen vaikutus rukiin kasvitautien esiintymiseen ja talvituhoihin}

\author{
Marjo Serenius, Erja Huusela-Veistola, Hanna Avikainen, Katri Pahkala ja Antti Laine \\ MTT (Maa- ja elintarviketalouden tutkimuskeskus)
}

\begin{abstract}
"Rukiin jalostuksen ja viljelyn tehostaminen pohjoisilla viljelyalueilla" -tutkimushankkeen yhdessä osahankkeessa on keskitytty rukiin uusien lajikkeiden viljelytekniikkaan. Monet rukiin kasvinsuojelukäytännöt ja ohjeet perustuvat 1950-1970-luvuilla tehtyihin tutkimuksiin, vaikka uusien lajikkeiden myötä muuttuva viljelytekniikka vaatii tarkennusta myös lajikkeiden kasvinsuojeluohjeisiin.

Tutkimuksemme tarkoituksena oli selvittää kylvöajan vaikutusta eri ruislajikkeiden kasvitautien torjuntatarpeeseen ja talvehtimiseen. Kasvitautien esiintymistä tutkittiin syksyllä ennen talvehtimista ja aikaisin keväällä. Lisäksi arvioitiin kylvöajan ja lajikkeen vaikutusta lumihomeen (Microdochium nivale) merkitykseen talvituhojen aiheuttajana. Tutkimus toteutettiin kenttäkokeena kolmella koepaikalla (Jokioinen, Pälkäne, Mietoinen) kahtena vuonna (1999-2001). Koetekijöinä olivat kylvöaika (aikainen kylvö viikolla 32, normaali kylvö viikolla 34 ja myöhäinen kylvö viikolla 36) ja lajike (suomalainen populaatiolajike Anna, puolalainen lyhytkortinen populaatiolajike Amilo, lyhytkortinen suomalainen linja Bor 7068 ja kaksi saksalaista hybridilajiketta, Esprit vuonna 1999 ja Picasso vuonna 2000).
\end{abstract}

Kasvitautien esiintyminen mitattiin kasvukauden päätyttyä lokakuun puolivälissä ja uudelleen kasvukauden alkaessa toukokuun alussa. Kasvinäytteistä laskettiin rukiin ruskearuosteen (Puccinia recondita f. sp. secalis) vioittamien kasvien prosentuaalinen määrä. Samoista kasvinäytteistä mitattiin myös taimien pituus ja kuivapaino. Oraiden ja versojen lukumäärä laskettiin kahden rivimetrin matkalta ruuduittain lokakuussa. Lumihomeen esiintyminen (0-100\% ruudun alasta) arvioitiin keväällä lumien sulettua huhtikuun lopussa. Talvituho laskettiin syksyllä ja keväällä tehtyjen kasvuston tiheysarvioiden (\%) avulla, ja se ilmensi talven aikana kuolleiden kasvien osuutta.

Kylvöaika vaikutti rukiin kasvitautien määrään. Rukiin ruskearuostetta oli eniten aikaisin kylvetyissä rukiissa ja selvästi vähemmän myöhään kylvetyissä kasvustoissa. Ruosteisten kasvien osuus väheni talven aikana rajusti aikaisissa kylvöissä, mutta lisääntyi myöhäisissä kylvöissä. Ruosteen vioittamia kasveja oli vähiten Amilo-rukiilla, mutta kylvöaika ja koepaikka vaikuttivat lajike-eroihin. Aikaisemmissa kylvöaikatutkimuksissa ruskearuosteen esiintyminen on liitetty runsaisiin kahukärpäsesiintymiin. Kuitenkin syksyllä 2000 rukiissa oli 
Serenius, $M$. et al. Disease infection in relation to sowing time of winter rye

paljon ruskearuostetta siitä huolimatta, että kahukärpäsvioitukset jäivät vähäisiksi kahukärpästorjunnasta johtuen. Ruskearuosteen runsauteen näyttääkin vaikuttavan ennen kaikkea syksyn lämpö- ja kosteusolot.

Lumihometta oli runsaimmin rehevissä kasvustoissa, jotka olivat koepaikasta ja koevuodesta riippuen joko aikaisin tai normaaliin aikaan kylvettyjä. Lajike-erot olivat selkeät: Anna ja Bor 7068 olivat kestävämpiä lumihomeelle kuin Amilo ja hybridilajikkeet Picasso ja Esprit. Lumihometta oli vähemmän Mietoisissa kuin Jokioisissa ja Pälkäneellä, mikä johtunee vähäisemmästä lumipeitteestä. Vuonna 1999 kylvetyissä rukiissa lumihomeen määrä oli pienempi harvoissa kasvustoissa ja vuonna 2000 matalissa kasvustoissa. Torjuntaruiskutus lumihometta vastaan on suositeltava ja jopa välttämätön ulkomaisia ruislajikkeita (Amilo, Picasso ja Esprit) viljeltäessä.

Talvituhomäärä vaihteli eri aikaan kylvetyissä ruiskasvustoissa koepaikoittain. Vähiten talvituhoa oli myöhään kylvetyissä kasvustoissa lukuun ottamatta Mietoisten talven 1999/2000 tuloksia. Lajike-erot talvituhossa olivat samansuuntaiset kuin lumihomeen kohdalla: kotimaiset lajikkeet Anna ja Bor 7068 olivat keskieurooppalaisia lajikkeita talvenkestävämpiä. Vuonna 1999 kylve- tyissä kasvustoissa runsas lumihomeen esiintyminen merkitsi myös suurempia talvituhoja. Vuonna 2000 perustetuissa kasvustoissa, jolloin lumihometta esiintyi puolet vähemmän, tätä ilmiötä ei havaittu. Jälkimmäisenä vuonna talvituho sen sijaan korreloi positiivisesti ruskearuosteen esiintymisen kanssa. Talvituho ja kahukärpästen määrä eivät vaikuttaneet toisiinsa.

Hyvin talvehtivat ja taudinkestävät lajikkeet turvaavat rukiin viljelyä maassamme. Rukiin aikainen kylvö lisää kuitenkin kasvinsuojeluongelmia, mikä vaikuttaa olennaisesti kasvuston alkukehitykseen. Jos halutaan vähentää rukiin kasvitauteja, ei ruista kannata kylvää liian aikaisin, vaan vasta elokuun puolivälistä eteenpäin. Kylvön viivyttäminen on suositeltavaa etenkin uusilla hybridilajikkeilla ja luomuviljelyssä. Vaikka tutkimuksessamme myöhään kylvetyssä rukiissa oli vähiten kasvitautiongelmia, on otettava huomioon, että koevuosien syksyt olivat poikkeuksellisen lämpimiä. Joinakin vuosina myöhään kylvetyt rukiit eivät välttämättä ehdi kehittyä tarpeeksi pitkälle ja karaistua ennen talventuloa, minkä seurauksena talvehtiminen ja keväinen kasvuun lähtö voi heiketä. Lisäksi myöhäinen kylvö voi vaikeutua tai jopa estyä sateiden vuoksi. 